\title{
9. GEOTHERMAL MEASUREMENTS DURING DEEP SEA DRILLING PROJECT LEG 801
}

\author{
J. P. Foucher, Centre Océanologique de Bretagne, Brest \\ P. Y. Chenet and L. Montadert, Institut Français du Pétrole, Rueil-Malmaison \\ and \\ J. M. Roux, Laboratoire de Mécanique Physique, Université de Bordeaux I
}

\begin{abstract}
Geothermal gradients were successfully determined from downhole temperature measurements at Sites 548,549 , and 550 . Mean determined temperature gradients are $27.2^{\circ} \mathrm{C} / \mathrm{km}$ between 110.5 and $281.5 \mathrm{~m}$ at Site $548,22.5^{\circ} \mathrm{C} / \mathrm{km}$ between 236.5 and $417 \mathrm{~m}$ at Site 549 , and $54.9^{\circ} \mathrm{C} / \mathrm{km}$ between 99.5 and $156.0 \mathrm{~m}$ at Site 550 .

We used over 200 conductivity measurements, including both onboard and shore-based determinations that were in good agreement, to find heat-flow values corrected for irregularities in seafloor topography and sediment-basement thermal conductivity contrast. The resulting values are $36 \pm 15 \mathrm{~mW} / \mathrm{m}^{2}, 37 \pm 15 \mathrm{~mW} / \mathrm{m}^{2}$, and $78 \pm 18 \mathrm{~mW} / \mathrm{m}^{2}$ for Sites 548,549 , and 550 , respectively. The Hercynian continental basement conductivity values average $3.8 \pm 0.4 \mathrm{~W} /$ $\mathrm{m}^{\circ} \mathrm{C}$. The average for the oceanic basalts at Site 550 is $1.6 \pm 0.1 \mathrm{~W} / \mathrm{m}^{\circ} \mathrm{C}$.

The heat-flow values at Sites 548 and 549 are comparable to those previously determined farther south on the north Biscay margin, in the Trevelyan-Meriadzek area, in particular the heat-flow determination of $36 \mathrm{~mW} / \mathrm{m}^{2}$ at Site 402 .

The thermal regime of the Goban Spur margin, as inferred from the heat-flow determinations at Sites 548 and 549, is compatible with a thermal model of continental margin evolution that assumes that the margin formed by lithospheric extension about $110 \mathrm{~m} . \mathrm{y}$. ago.

The heat contribution from the radioelements in the crust probably does not differ significantly from Site 548 to Site 549 , and is estimated to be less than $10 \mathrm{~mW} / \mathrm{m}^{2}$.

The heat flow of $78 \mathrm{~mW} / \mathrm{m}^{2}$ at Site 550 is abnormally high for an ocean crust thought to have formed about 100 m.y. ago.
\end{abstract}

\section{INTRODUCTION}

On Leg 80 , four holes were drilled on a transect across the Goban Spur area (Fig. 1), providing a unique opportunity to determine the heat flow rates and document the thermal regime of the deeper part of a mature continental margin and the adjacent ocean crust.

A particular attraction in carrying out a geothermal investigation of the Goban Spur area is that rifting took place there in a probably simple geological context. On the Goban Spur, rifting affected a Hercynian granitic and metasedimentary basement with a thin sediment cover. This is a simpler geological context than that, for example, in the Meriadzek-Trevelyan area, farther south of the Goban Spur, in the northern Bay of Biscay, where a thick Mesozoic sequence occurs, evidencing large Mesozoic vertical movements and a probably more complicated geological context. To our sense this makes a comparison of the present-day thermal structure of the Goban Spur area with that of the Hercynian continental borderland quite desirable, since different geothermal conditions in the two areas are likely to be the result of the only thermal effects associated with the rifting event.

Heat flow was successfully determined at Sites 548, 549 , and 550 . Together with a previous heat-flow deter-

\footnotetext{
${ }^{1}$ Graciansky, P. C. de, Poag, C. W., et al., Init. Repts. DSDP, 80: Washington (U.S. Govt, Printing Office).

Addresses: (Foucher) Centre Océanologique de Bretagne, B.P. 337, 29273 Brest Cedex, France; (Chenet, Montadert) Institut Français du Pétrole, B.P. 311, 92506 Rueil-Malmaison Cedex, France; (Roux) Laboratoire de Mécanique Physique, Université de Bordeaux I, 351, Cours de la Libération, 33405, Talence Cedex, France.
}

mination at DSDP Site 402 (Erickson et al., 1979) and early conventional surface heat-flow measurements (Foucher and Sibuet, 1980), the new Leg 80 heat-flow determinations contribute toward further outlining the regional trends in the thermal regime of the northern Bay of Biscay margin.

\section{TEMPERATURE MEASUREMENTS}

\section{Methods}

All temperature data are downhole data acquired using the DSDP downhole temperature probe described by Yokota et al. (1980). The measurement technique consists in lowering to the bottom of the hole the temperature probe, rigidly secured to the lower end of the core barrel, and driving the probe into the undrilled, thermally undisturbed sediment ahead of the drill bit. The probe is pushed into the sediment by using, as the driving force, the weight of the bottom-hole assembly, into which the probe has been previously latched. The probe includes a self-contained recorder. The sensor temperature is sampled every minute for a total measuring time, after insertion of the probe into the sediment, of about $30 \mathrm{~min}$. In normal operating conditions, the sensor has reached or closely approached the equilibrium sediment temperature at the end of the measurement time. In this case, the accuracy of the temperature measurement is probably within $0.05^{\circ} \mathrm{C}$.

The quality of the measurements depends on several critical factors, some of which are difficult to control. Clearly, two main factors are the depth of insertion of 
the probe into the sediment and the degree of stabilization of the probe in the sediment. In extreme cases-either of too hard rocks, which prevent normal penetration of the probe into the sediment, or of vertical movements of the probe after its insertion into the sediment, which produce large frictional heating-measurements are unsuccessful.

\section{Results}

Table 1 summarizes the downhole temperature measurements attempted during Leg 80 .

\section{Hole 548A}

Temperatures were measured at four levels in Hole 548A (Fig. 2). Two good quality measurements, at 110.5 and $281.5 \mathrm{~m}$ sub-bottom, were used to calculate a mean temperature gradient of $27.2^{\circ} \mathrm{C} / \mathrm{km}$. By extrapolation of this gradient to the sea bottom, a bottom seawater temperature of $9.9^{\circ} \mathrm{C}$ was calculated; this is significantly higher than the measured value between 7.1 and $7.6^{\circ} \mathrm{C}$. The approximately $2^{\circ} \mathrm{C}$ difference between the observed and calculated temperatures can be ascribed to the known seasonal fluctuations of bottom-water temperature at the location of Hole 548A. Hole 548A is the hole drilled at the shallowest water depth during Leg 80 , only $1251 \mathrm{~m}$.

\section{Hole 549}

Seven temperature measurements were attempted in Hole 549 at six different levels (of which four are represented in Fig. 3). The three measurements at sub-bottom depths of $198.5,236.5$, and $417.0 \mathrm{~m}$ gave good quality

Table 1. Summary of downhole temperature measurements, Leg 80 .

\begin{tabular}{|c|c|c|}
\hline $\begin{array}{l}\text { Sub-bottom } \\
\text { depth } \\
\text { (m) }\end{array}$ & $\begin{array}{c}\text { Temperature } \\
\left({ }^{\circ} \mathrm{C}\right)\end{array}$ & $\begin{array}{l}\text { Quality/ } \\
\text { observations }\end{array}$ \\
\hline \multicolumn{3}{|l|}{ Hole 548A } \\
\hline 0 & $7.1-7.6$ & Good \\
\hline 53.5 & & No stabilization \\
\hline 110.5 & 12.9 & Excellent \\
\hline 167.5 & & No stabilization \\
\hline 281.5 & 17.5 & Good \\
\hline \multicolumn{3}{|l|}{ Hole 549} \\
\hline 0 & 3.4 & Excellent \\
\hline 95.0 & & No recording \\
\hline 151.0 & & No recording \\
\hline 198.5 & 10.0 & Good \\
\hline 236.5 & 9.9 & Good \\
\hline 274.5 & & No penetration \\
\hline 274.5 & $10.4 ?$ & No stabilization \\
\hline 417.0 & $13.3-13.6$ & Good \\
\hline \multicolumn{3}{|l|}{ Hole 550} \\
\hline 0 & $2.6-2.7$ & Good \\
\hline 99.5 & 6.6 & Excellent \\
\hline 156.5 & 9.7 & Excellent \\
\hline 213.5 & & Uncertain penetration \\
\hline \multicolumn{3}{|l|}{ Hole $550 \mathrm{~B}$} \\
\hline 0 & 2.8 & Good \\
\hline 323.0 & $16.0 ?$ & No stabilization \\
\hline
\end{tabular}

temperature determinations. There is, however, some uncertainty as to the value of $10^{\circ} \mathrm{C}$ obtained at $198.5 \mathrm{~m}$, since the bottom-water temperature of $7.2^{\circ} \mathrm{C}$ derived from the temperature record for this measurement is clearly not valid. It will be also noted that the temperature at $417.0 \mathrm{~m}$ had not fully stabilized at the end of the measuring time. The minimum temperature recorded at this depth was $13.6^{\circ} \mathrm{C}$. A possibly better estimate, obtained from a simple plot of the temperature versus the inverse of time, is $13.3^{\circ} \mathrm{C}$. The mean geothermal gradient calculated between the 236.5 and $417.0 \mathrm{~m}$ depths is $20.5^{\circ} \mathrm{C} / \mathrm{km}$, taking a temperature of $13.6^{\circ} \mathrm{C}$ at $417.0 \mathrm{~m}$, or $24.4^{\circ} \mathrm{C} / \mathrm{km}$, taking the temperature at that depth to be $13.3^{\circ} \mathrm{C}$. We consider this range of values, 20.5 to $24.4^{\circ} \mathrm{C} / \mathrm{km}$, as the best estimate of the geothermal gradient in Hole 549.

\section{Hole 550}

Three temperature measurements were attempted in Hole 550 (Figs. 4A-4C). Two excellent temperature determinations, at 99.5 and $156.5 \mathrm{~m}$ sub-bottom depth, give a mean temperature gradient value of $54.9^{\circ} \mathrm{C} / \mathrm{km}$.

\section{Hole 550B}

A temperature measurement was attempted at a subbottom depth of $323 \mathrm{~m}$ (Fig. 4D). The measurement is of very poor quality, owing to apparent frictional movements of the probe in the sediment, causing temperature disturbances. A rough estimate of the sediment temperature, about $16^{\circ} \mathrm{C}$, can be obtained by looking at the shape of the temperature record. In spite of its large uncertainty, a major interest of this estimate is that it tends to confirm the high temperature gradient calculated for Hole 550. One will note that the $16^{\circ} \mathrm{C}$ temperature value nearly aligns with other temperature data for Site 550 on a temperature-versus-depth plot (Fig. 5).

\section{THERMAL CONDUCTIVITY MEASUREMENTS}

In total, 142 conductivity measurements were made in the shipboard laboratory on recovered samples from Sites 549 and 550, using the needle-probe technique (Von Herzen and Maxwell, 1959).

\section{Methods}

The needle-probe technique was originally developed to measure the thermal conductivity of a soft sediment sample, in which case the needle-probe is inserted into the sediment sample. Thermal conductivities of hard rock samples can also be measured, using a half-space adaptation of the method (Carvalho et al, 1980), with the needle sensor applied to the polished flat surface of a rock sample. During Leg 80 , thermal conductivities of hard rock samples were measured using the half-space version of the method. The probe was calibrated using a fused-silica standard $\left(1.38 \mathrm{Wm}^{-1} \mathrm{~K}^{-1}\right)$. The accuracy of the needle-probe technique has been estimated to be within 5\% (Von Herzen and Maxwell, 1959).

In addition to the shipboard needle-probe measurements, 61 steady-state measurements were completed ashore, after the cruise, on rock samples from Sites 549 and 550 , in a thorough experimental study of a newly 
developed hotplate-type thermal-conductivity measurement device (Roux, 1982; and see Appendix).

\section{Results}

Tables 2 and 3 summarize all the conductivity data acquired using the needle-probe technique and the hotplate steady-state method. The data show the normal increase of thermal conductivity with depth, from mean values around $1.5 \mathrm{~W} / \mathrm{m}^{\circ} \mathrm{C}$ just below the seafloor to more than $3.5 \mathrm{~W} / \mathrm{m}^{\circ} \mathrm{C}$ near the bottom of Hole 549 (Table 2). Conductivities measured on the Paleozoic micaceous sandstones of the basement sampled at this hole average $3.8 \pm 0.4 \mathrm{~W} / \mathrm{m}^{\circ} \mathrm{C}$. In Hole $550 \mathrm{~B}$, the conductivity decreases in basalts near the bottom of the hole (Table 3 ). The mean thermal conductivity measured on the basalt samples is $1.60 \pm 0.1 \mathrm{~W} / \mathrm{m}^{\circ} \mathrm{C}$ in this hole. This value is in close agreement with previously reported conductivity values for basalts: for example, $1.66 \pm$ $0.02 \mathrm{~W} / \mathrm{m}^{\circ} \mathrm{C}$ for DSDP Leg 37 basalts (Hyndman and Drury, 1976).

\section{Comparison of Thermal Conductivity Data Acquired Using the Needle-Probe Technique and the Hotplate Apparatus}

Steady-state measurements could not be made on the same rock samples used on board the ship for needleprobe measurements. This prevents direct comparison of the conductivity data acquired using the two methods. Nevertheless, comparison of the mean conductivity values over the same depth intervals suggests good agreement between results obtained using the needle-probe technique and those obtained with the hotplate apparatus (Table 4).

\section{Dependence of Conductivity on Temperature}

Preliminary experiments on four sedimentary samples from Hole 549 indicate a decrease of the conductivity by an amount between 0.007 and $0.011 \mathrm{~W} / \mathrm{m}^{\circ} \mathrm{C}$ per degree over the temperature range zero to $80^{\circ} \mathrm{C}$ (Fig. 6).

Table 2. Thermal conductivity measurements at Site 549.

\begin{tabular}{|c|c|c|c|c|c|}
\hline Core-Section & $\begin{array}{l}\text { Sub-bottom } \\
\text { depth } \\
\text { (m) }\end{array}$ & $\begin{array}{l}\text { Thermal } \\
\text { conductivity } \\
\left(\mathrm{W} / \mathrm{m}^{\circ} \mathrm{C}\right)\end{array}$ & Core-Section & $\begin{array}{l}\text { Sub-bottom } \\
\text { depth } \\
\text { (m) }\end{array}$ & $\begin{array}{l}\text { Thermal } \\
\text { conductivity } \\
\left(\mathrm{W} / \mathrm{m}^{\circ} \mathrm{C}\right)\end{array}$ \\
\hline Hole 549A & \multicolumn{2}{|c|}{ Needle-probe apparatus } & Hole 549 & \multicolumn{2}{|c|}{ Needle-probe apparatus (Cont.) } \\
\hline $2-1$ & 9 & 1.509 & $84-1$ & 885 & 2.567 \\
\hline $4-1$ & 28 & 1.395 & $84-1$ & 885 & 3.468 \\
\hline $4-1$ & 26 & 1.624 & $84-1$ & 885 & 2.376 \\
\hline $6-1$ & 47 & 1.442 & $85-2$ & 888 & 2.037 \\
\hline $8-1$ & 66 & 1.410 & $85-2$ & 888 & 1.782 \\
\hline $10-1$ & 85 & 1.509 & $87-2$ & 906 & 3.377 \\
\hline $12-1$ & 104 & 1.395 & $89-2$ & 921 & 2.468 \\
\hline $14-1$ & 112 & 1.395 & $90-1$ & 929 & 2.984 \\
\hline $16-1$ & 120 & 1.458 & $92-1$ & 947 & 2.790 \\
\hline $18-1$ & 125 & 1.426 & & & \\
\hline 24-1 & 133 & 1.546 & Hole 549 & \multicolumn{2}{|c|}{ Steady-state apparatus } \\
\hline $26-1$ & 138 & 1.509 & & & \\
\hline $28-1$ & 141 & 1.442 & $14-3$ & 313 & 2.431 \\
\hline $32-1$ & 149 & 1.565 & $34-1$ & 502 & 1.682 \\
\hline $34-1$ & 157 & 1.527 & $42, \mathrm{CC}$ & 570 & 1.568 \\
\hline \multirow[t]{2}{*}{$34-1$} & 157 & 1.565 & $43-1$ & 580 & 2.051 \\
\hline & & & 44-4 & 590 & 1.724 \\
\hline \multirow[t]{2}{*}{ Hole 549} & \multirow{2}{*}{\multicolumn{2}{|c|}{ Needle-probe apparatus }} & $46-3$ & 608 & 1.437 \\
\hline & & & $47-4$ & 620 & 1.681 \\
\hline $22-3$ & 392 & 1.833 & $52-1$ & 664 & 3.263 \\
\hline $24-3$ & 412 & 1.798 & $57-4$ & 714 & 2.280 \\
\hline $28-1$ & 449 & 1.746 & $58-6$ & 726 & 2.130 \\
\hline 28-1 & 449 & 2.005 & $59-1$ & 730 & 2.153 \\
\hline $28-2$ & 449 & 1.825 & $60-6$ & 740 & 2.222 \\
\hline $28-2$ & 449 & 2.145 & $61-1$ & 750 & 2.188 \\
\hline $28-2$ & 449 & 1.630 & $72-1$ & 800 & 1.916 \\
\hline 26-2 & 449 & 1.746 & $72-2$ & 806 & 2.161 \\
\hline $29-1$ & 455 & 1.972 & $73-1$ & 809 & 2.301 \\
\hline $40-1$ & 550 & 1.825 & $73-3$ & 834 & 2.802 \\
\hline $42-2$ & 570 & 1.941 & $77, \mathrm{CC}$ & 845 & 2.485 \\
\hline $42-2$ & 570 & 1.853 & $78-1$ & 865 & 2.702 \\
\hline $44-4$ & 593 & 1.911 & $80-2$ & 875 & 2.698 \\
\hline $46-1$ & 608 & 1.798 & $81-1$ & 875 & 2.698 \\
\hline $52-1$ & 664 & 3.955 & $82-2$ & 875 & 2.697 \\
\hline $56-5$ & 701 & 1.915 & 83-2 & 880 & 3.104 \\
\hline $56-4$ & 705 & 1.974 & $86-3$ & 900 & 2.202 \\
\hline $57-1$ & 711 & 2.619 & $87-2$ & 910 & 3.001 \\
\hline $57-3$ & 713 & 2.516 & $88-3$ & 915 & 2.925 \\
\hline $57-4$ & 715 & 2.566 & $90-2$ & 930 & 3.142 \\
\hline $74-3$ & 815 & 3.377 & $91-3$ & 940 & 2.553 \\
\hline $74-2$ & 813 & 2.421 & $95-1$ & 973 & 3.680 \\
\hline $76-2$ & 827 & 2.421 & $96-1$ & 980 & 4.342 \\
\hline $81-1$ & 861 & 2.333 & $97-1$ & 985 & 3.062 \\
\hline $83-1$ & 879 & 2.251 & $98-1$ & 990 & 4.062 \\
\hline
\end{tabular}


Table 3. Thermal conductivity measurements at Site 550.

\begin{tabular}{lcc}
\hline Core-Section & $\begin{array}{c}\text { Sub-bottom } \\
\text { depth } \\
(\mathrm{m})\end{array}$ & $\begin{array}{c}\text { Thermal } \\
\text { conductivity } \\
\left(\mathrm{W} / \mathrm{m}^{\circ} \mathrm{C}\right)\end{array}$ \\
\hline Hole 550 & Needle-probe apparatus
\end{tabular}

$\begin{array}{lll}4-1 & 120 & 1.450 \\ 6-1 & 146 & 1.510 \\ 8-4 & 161 & 1.402 \\ 10-1 & 180 & 1.351 \\ 12-4 & 200 & 1.565 \\ 14-2 & 218 & 1.555 \\ 15-1 & 224 & 1.782 \\ 16-3 & 233 & 1.492 \\ 17-2 & 244 & 1.527 \\ 18-3 & 255 & 1.458 \\ 19-2 & 261 & 1.614 \\ 21-2 & 282 & 1.555 \\ 23-1 & 301 & 1.711 \\ 24-1 & 311 & 1.456 \\ 25-4 & 323 & 1.527 \\ 26-1 & 327 & 1.458 \\ 27-5 & 343 & 1.645 \\ 28-1 & 347 & 1.758 \\ 29-1 & 357 & 1.833 \\ 30-1 & 365 & 1.860 \\ 31-1 & 376 & 1.645 \\ 32-1 & 385 & 1.758 \\ 34-1 & 404 & 1.711 \\ 33-1 & 394 & 1.700 \\ 34-1 & 404 & 1.667 \\ 36-4 & 427 & 1.711 \\ 37-1 & 432 & 1.85 \\ 39-2 & 452 & 1.758 \\ 38-4 & 445 & 1.624 \\ 40-1 & 460 & 2.139 \\ 42-1 & 480 & 1.666 \\ 43-1 & 489 & 2.070 \\ & & \end{array}$

Hole 550B Needle-probe apparatus

$\begin{array}{lll}3-2 & 477 & 2.07 \\ 4-1 & 485 & 1.915 \\ 5-1 & 494 & 1.944 \\ 7-2 & 515 & 2.121 \\ 8-4 & 527 & 2.271 \\ 9-4 & 537 & 2.139 \\ 10-4 & 546 & 2.07 \\ 11-1 & 551 & 2.175 \\ 12-4 & 565 & 2.271 \\ 16-1 & 598 & 2.037 \\ 17-2 & 610 & 3.418 \\ 18-1 & 618 & 2.121\end{array}$

Hole 550B Steady-state apparatus

$\begin{array}{lll}4-1 & 485 & 1.975 \\ 10-3 & 545 & 1.801 \\ 13-7 & 580 & 1.534 \\ 20-4 & 640 & 1.527 \\ 22-4 & 655 & 1.742 \\ 25-4 & 685 & 1.425\end{array}$

\section{Correlation between Porosity and Thermal Conductivity}

Variations in thermal conductivity with depth are correlated with variations in porosity (Figs. 7 and 8). The dependence of thermal conductivity on porosity can be described, to a first approximation, by a linear law. The following laws were calculated by a least-squares fitting technique. For Site 549,

$$
K=3.26-0.031 \epsilon \quad(\text { Correlation factor }=0.76)
$$

and for Site 550,

$$
K=2.25-0.012 \epsilon \quad(\text { Correlation factor }=0.54)
$$

with $K$, thermal conductivity, in $\mathrm{W} / \mathrm{m}^{\circ} \mathrm{C}$ and $\epsilon$, porosity, in percent.

\section{HEAT-FLOW ESTIMATES AND CORRECTIONS}

Heat flow is calculated as the product of the geothermal gradient and the thermal conductivity. The selected conductivity value is the inverse of the mean thermal resistivity over the depth interval used for determining the geothermal gradient. At Site 548, where no conductivity data are available, conductivity was estimated using data from Sites 549 and 550, as it is noted that conductivity values do not significantly differ from one site to the other at similar depths.

Table 5 summarizes the heat-flow results for Sites 548, 549 , and 550 . Calculated heat-flow values were subsequently corrected to account for lateral heat-conduction effects caused by changes in topography and contrasts in thermal conductivity (Fig. 9). Corrections amount to only a few percent.

\section{DISCUSSION}

Low heat-flow values were obtained at Sites 548 and 549 on the transitional crust of the Goban Spur area: 36 and $37 \mathrm{~mW} \mathrm{~m}^{2}$, respectively. These values do not significantly differ from previously reported heat-flow determinations farther south on the north Bay margin, in the Meriadzek-Trevelyan area. In that area, heat flow was estimated to be $36 \mathrm{~mW} / \mathrm{m}^{2}$ (Erickson et al., 1979) at DSDP Site 402, and surface measurements (Fig. 10) were reported in the range 36 to $43 \mathrm{~mW} / \mathrm{m}^{2}$ (Foucher and Sibuet, 1980). It can be suggested, therefore, that the whole deeper part of the north Biscay margin is characterized, on a regional scale, by relatively low heat-flow values, around $40 \mathrm{~mW} / \mathrm{m}^{2}$.

Heat-flow values at Site 548 are similar to those at Site 549. This is a notable result, since the crust at Site 549 , in $3485 \mathrm{~m}$ of water, is expected to be considerably thinner than that at Site 548 , in only $1691 \mathrm{~m}$ of water. On the assumption that local isostasy conditions prevail

Table 4. Comparison of the conductivity data obtained using the needle-probe technique and using the hotplate apparatus.

\begin{tabular}{ccc}
\hline $\begin{array}{c}\text { Sub-bottom } \\
\text { depth } \\
\text { interval } \\
(\mathrm{m})\end{array}$ & $\begin{array}{c}\text { Transient method } \\
\text { (needle-probe } \\
\text { technique) }\end{array}$ & $\begin{array}{c}\text { Steady-state method } \\
\text { (hotplate } \\
\text { apparatus) }\end{array}$ \\
\hline Hole 549 & & \\
$400-600$ & $1.86 \pm 0.13(13)$ & $1.89 \pm 0.35(5)$ \\
$600-750$ & $2.48 \pm 0.75(7)$ & $2.17 \pm 0.53(8)$ \\
$750-950$ & $2.62 \pm 0.52(14)$ & $2.63 \pm 0.36(16)$ \\
Hole 550B & & \\
$450-685$ & $2.21 \pm 0.39(12)$ & $1.67 \pm 0.21(6)$ \\
\hline
\end{tabular}

Note: Number of measurements in parentheses. 
Table 5. Summary of Leg 80 heat-flow results.

\begin{tabular}{|c|c|c|c|c|c|}
\hline Site & $\begin{array}{l}\text { Sub-bottom } \\
\text { depth } \\
\text { interval } \\
\text { (m) }\end{array}$ & $\begin{array}{c}\text { Temperature } \\
\text { gradient } \\
\left(10^{-3}{ }^{\circ} \mathrm{C} / \mathrm{m}\right)\end{array}$ & $\begin{array}{l}\text { Mean thermal } \\
\text { conductivity } \\
\left(\mathrm{W} / \mathrm{m}^{\circ} \mathrm{C}\right)\end{array}$ & $\begin{array}{l}\text { Uncorrected } \\
\text { heat flow } \\
\left(\mathrm{mW} / \mathrm{m}^{2}\right)\end{array}$ & $\begin{array}{c}\text { Estimated heat flow } \\
\text { at a depth of } \\
6 \mathrm{~km} \text { below } \\
\text { the sea surface } \\
\left(\mathrm{mW} / \mathrm{m}^{2}\right)\end{array}$ \\
\hline 548 & $110.0-281.5$ & 27.2 & $1.50^{\mathrm{a}}$ & $41 \pm 15$ & $36 \pm 15$ \\
\hline 549 & $236.0-417.0$ & 20.5 & 1.82 & $37 \pm 10$ & $37 \pm 14$ \\
\hline 550 & $99.5-156.0$ & 54.9 & 1.48 & $81 \pm 20$ & $78 \pm 18$ \\
\hline
\end{tabular}

${ }^{\mathrm{a}}$ Estimated from Sites 549 and 550.

(which is a simple assumption, made in the absence of direct seismic information on the crustal structure at or in the vicinity of the drilling sites), the crust at Site 549 would be more than $10 \mathrm{~km}$ thinner than at Site 548 . The observed lack of any significant difference between the heat-flow values at Sites 548 and 549, despite expected substantially different crustal thicknesses, tends to confirm the earlier observation by Foucher and Sibuet (1980) that there is no significant heat-flow variation across the Meriadzek-Trevelyan area, although the crustal thickness decreases seaward from $20 \mathrm{~km}$ to $6 \mathrm{~km}$ (Avedik et al., 1981).

In interpreting heat-flow data from the top of a continental margin, it is usual to consider the heat-flow values as the sums of three components: the heat from the mantle, the heat produced by the radioelements in the crust, and the transient heat flux associated with the thermal rifting event. In the case of the Goban Spur margin, the rifting event ended about 110 m.y. ago (Masson et al., this vol.), which implies that the transient heat flux associated with the rifting event is unlikely to exceed $10 \mathrm{~mW} / \mathrm{m}^{2}$ (McKenzie, 1978).

This therefore leaves, for the sum of the heat flow from the mantle and the heat originating from the radioelements in the crust, a value of 26 to $36 \mathrm{~mW} / \mathrm{m}^{2}$. This is a low value, and suggests, when compared with the mantle heat-flow estimate for the U.K. by Oxburgh et al. (1980) of $27 \mathrm{~mW} / \mathrm{m}^{2}$, that the radioelements in the crust at Sites 548 and 549 contribute to the surface heat flow at these sites by less than $10 \mathrm{~mW} / \mathrm{m}^{2}$.

Whether this low estimate of $10 \mathrm{~mW} / \mathrm{m}^{2}$ for the crustal heat production could result from a large decrease associated with rifting of an initially high crustal contribution in the pre-rifting stage, or from a low or vanishingly small decrease of an initially low crustal contribution, is difficult to establish, because of the large possible range of values that can be assumed for the initial crustal contribution: from less than 20 to more than $80 \mathrm{~mW} / \mathrm{m}^{2}$, as one may estimate from a recent analysis of the heat-flow determinations on the U.K. and French borderland (Oxburgh et al., 1980; Vasseur et al., 1980).

Nevertheless, the fact that similar heat-flow values were obtained at Sites 548 and 549, and farther south across the Meriadzek-Trevelyan area, even though variations in crustal thickness are large, tends to indicate that similar quantities of heat are produced by the crust at the different sites sampled or drilled across the margin, despite considerably different amounts of crustal thinning. This conclusion rests on the assumption that the heat flowing from the mantle remains constant or nearly constant at all these sites.

Does this result provide clues on the nature of the crustal thinning processes across the margin (Le Pichon and Sibuet, 1981; Chenet et al., 1982; Brun and Choukroune, 1983)? Comparable crustal heat productions suggest comparable amounts of stretching of the upper crustal layer, where radioelements are thought to concentrate. This means that the amount of stretching of the upper crust may not increase as rapidly as the amount of crustal thinning across the margin, which implies nonuniform amounts of crustal thinning with depth during rifting.

Finally, an interesting result is the surprisingly high heat-flow value of $78 \mathrm{~mW} / \mathrm{m}^{2}$ obtained at Site 550 . This site is on ocean crust formed about 100 m.y. ago (Masson et al., this vol.). Typical heat-flow values for ocean crust of this age are 45 to $55 \mathrm{~mW} / \mathrm{m}^{2}$. The high heat-flow value could result from additional heat brought close to the surface by convective processes in the faulted basement observed near this site. Further measurements would be required to map the geothermal anomaly and clarify the thermal structure near Site 550 .

\section{SUMMARY AND CONCLUSIONS}

1. Geothermal gradients were successfully determined at Sites 548, 549, and 550. The geothermal gradients were converted to heat-flow values, using over 200 thermal conductivity measurements on samples from Sites 549 and 550. Determined heat-flow values, after corrections for topography and sedimentary effects, are $36 \pm$ $13 \mathrm{~mW} / \mathrm{m}^{2}$ at Site $548,37 \pm 14 \mathrm{~mW} / \mathrm{m}^{2}$ at Site 549 , and $78 \pm 18 \mathrm{~mW} / \mathrm{m}^{2}$ at Site 550 .

2. Low heat-flow values at Sites 548 and 549 , on the transitional crust of the Goban Spur margin, tend to confirm that the northern Bay of Biscay margin is thermally characterized by heat-flow values somewhat lower than on the Hercynian borderland. The crustal contribution to the surface heat flow at Sites 548 and 549 is estimated to be less than $10 \mathrm{~mW} / \mathrm{m}^{2}$.

3. The thermal regime of the Goban Spur margin is compatible with a thermal model of continental margin evolution that assumes that the margin formed by lithospheric extension about 110 m.y. ago. That no decrease in the heat flow occurs from Site 548 to Site 549, though the crust becomes thinner by probably more than 10 $\mathrm{km}$, may indicate similar amounts of extension of the upper crust at Sites 548 and 549, despite considerably different amounts of crustal thinning. 
4. The heat-flow determination of $78 \mathrm{~mW} / \mathrm{m}^{2}$ at Site 550 is abnormally high for an ocean crust thought to have formed about 100 m.y. ago. Further measurements in the area would be required to clarify the geothermal field. The high heat-flow determination has not been confirmed by recent surface heat-flow measurements, which, instead, indicate a regional heat flow of 50 to $60 \mathrm{~mW} /$ $\mathrm{m}^{2}$ (Sibuet, personal communication).

\section{ACKNOWLEDGMENTS}

We are grateful to Claude Jaupart for a helpful review.

\section{REFERENCES}

Avedik, F., Camus, A. L., Ginzburg, A., Montadert, L., Roberts, D. G., et al., 1982. A seismic refraction and reflexion study of the continent-ocean transition beneath the north Biscay margin. Phil. Trans. R. Soc. London Ser. A, 305:5-25.

Brun, J. P., and Choukroune, P., 1983. Normal faulting, block tilting, and décollement in a stretched crust. Tectonophysics, 2:345-356.

Carvalho, H. da S., Purwoko, S., Thamrin, M., and Vacquier, V., 1980. Terrestrial heat flow in the Tertiary basin of central Sumatra. Tectonophysics, 69:163-188.

Chenet, P. .Y., Montadert, L., Gairaud, H., and Roberts, D. F., 1982. Extension ratio measurements on the Galicia, Portugal and northern Biscay continental margins. Implications for some evolution models of passive continental margins. Mem. Am. Assoc. Petrol. Geol., 34:703-715.

de Graciansky, P. C., Poag, C. W., et al., in press. The Goban Spur transect-geological evolution of a sediment-starved passive continental margin. Geol. Soc. Am. Bull.

Erickson, A. J., Avera, W. E., and Byrne, R., 1979. Heat flow results, DSDP Leg 48. In Montadert, L., Roberts, D. G., et al., Init. Repts. $D S D P, 48$ : Washington (U.S. Govt. Printing Office), 277-288.

Foucher, J. P., and Sibuet, J. C., 1980. Thermal regime of the northern Bay of Biscay continental margin in the vicinity of the DSDP Site 400-402. Phil. Trans. R. Soc. London Ser. A, 294:157-167.

Hyndman, R. D., and Drury, M. J., 1976. The physical properties of oceanic basement rocks from deep drilling on the Mid-Atlantic Ridge. J. Geophys. Res., 81:4042-4052.

Le Pichon, X., and Sibuet, J. C., 1981. Passive margins, a model of formation. J. Geophys, Res., 86:3708-3720.

McKenzie, D., 1978. Some remarks on the development of sedimentary basins. Earth Planet Sci. Lett., 40:25-32.

Montadert, L., Roberts D. G., de Charpal, O., and Guennoc, P., 1979. Rifting and subsidence of the northern continental margin of the Bay of Biscay. In Montadert, L., Roberts, D. G., et al., Init. Repts. $D S D P, 48$ : Washington (U.S. Govt. Printing Office), 1025-1060.

Oxburgh, E. R., Richardson, S. W., Wright, S. M., Jones, M. Q. W., Penny, S. R., et al., 1980. Heat flow pattern of the United Kingdom. In Strub, A. S., and Ungemach, P. (Eds.), Proc. Second Internat. Seminar on Results of EC Geothermal Energy Res.: D. Reidel, pp. 447-455.

Roux, J. M., 1982. Étude de conductivimètres pour les hautes et basses températures. Application à la mesure du flux géothermique dans les sédiments marins [Thèse]. Université de Bordeaux I.

Vasseur, G., and Groupe FLUXCHAF, 1980. A statistical study of heat-flow data in France. In Strub, A. S., and Ungemach, P. (Eds.), Proc. Second Internat. Seminar on Results of EC Geothermal Energy Res.: D. Reidel, pp. 474-484.

Von Herzen, R. P., and Maxwell, A. E., 1959. The measurement of thermal conductivity of deep-sea sediments by a needle-probe method. J. Geophys. Res., 64:1557-1563.

Watremez, P., 1980. Flux de chaleur sur le massif armoricain et sur la marge continentale: essai de modélisation de l'évolution thermique de la marge armoricaine [Thèse]. Université de Brest.
Yokota, T., Kinoshita, H., and Uyeda, S., 1980. New DSDP (Deep Sea Drilling Project) downhole temperature probe utilizing ICRAM (memory) elements. Bull. Earthquake Res. Inst., Univ. Tokyo, 54: 441-462.

Date of Initial Receipt: August 23, 1983

Date of Acceptance: February 29, 1984

\section{APPENDIX}

\section{Steady-State Measurements of Thermal Conductivity}

The principle of the steady-state technique is to compare the thermal conductivity of a given sample to the conductivity of a standard. For this purpose, a heating element is placed between the sample and the standard (Fig. 11A). Both extremities of the cylinder of section $s$ are maintained at a constant temperature $T_{1}$, and a constant quantity of electrical power $W$ is supplied in the central heater. When steadystate conditions are reached, the central heater is at a constant temperature $T_{1}+\Delta T$ (Fig. 11B). Let us designate by

$\lambda_{1}$ the thermal conductivity of the sample 1 , by

$\lambda_{2}$ the thermal conductivity of the sample 2 , and by

$E$ the thickness of the samples.

If lateral thermal flow is neglected, Fourier's law can be expressed in monodimensional form in sample 1 and in sample 2:

$$
\begin{gathered}
\text { For sample 1: } \Phi_{1}=\lambda_{1} \frac{\Delta T}{E} ; \\
\Phi_{1}=\text { heat flux through sample 1. } \\
\text { For sample 2: } \Phi_{2}=\lambda_{2} \frac{\Delta T}{E} ; \\
\Phi_{2}=\text { heat flux through sample } 2 .
\end{gathered}
$$

The total heat loss, $W$, across the external sides of the apparatus, is equal to the electrical power:

$$
W=\phi_{1} s+\phi_{2} s
$$

where $s$ is the surface of each external side. The mean conductivity is then expressed by

$$
\lambda_{m}=\frac{\lambda_{1}+\lambda_{2}}{2}=W / 2 s \cdot \frac{E}{\Delta T}
$$

If the thermal conductivity $\lambda_{1}$ of one of the samples is known with accuracy, the measurement concerns $\lambda_{2}$, and

$$
\lambda_{2}=W / s \cdot\left(\frac{E}{\Delta T}\right)-\lambda_{1}
$$

In the expression of the thermal conductivity (1), the lateral heat flow is neglected. To predict this lateral thermal loss, we use a finite-element method to compute a correction factor, $\alpha$, defined by

$$
\bar{\lambda}_{\text {real }}=\alpha \bar{\lambda}_{m}
$$

It is a cylindrical geometry problem. Figure $11 \mathrm{C}$ shows the network used with the boundary conditions. The finite-element program involves (1) determination of the heat flux through the boundary, and (2) calculation of the nodal temperature. The computation was performed for different values of the $\Lambda$ parameter, where $\Lambda$ is the ratio between the average thermal conductivity $\lambda_{m}$ and the insulating thermal conductivity $\lambda_{i}$. The correction factor is also a function of the thickness of the sample (see Fig. 12). 


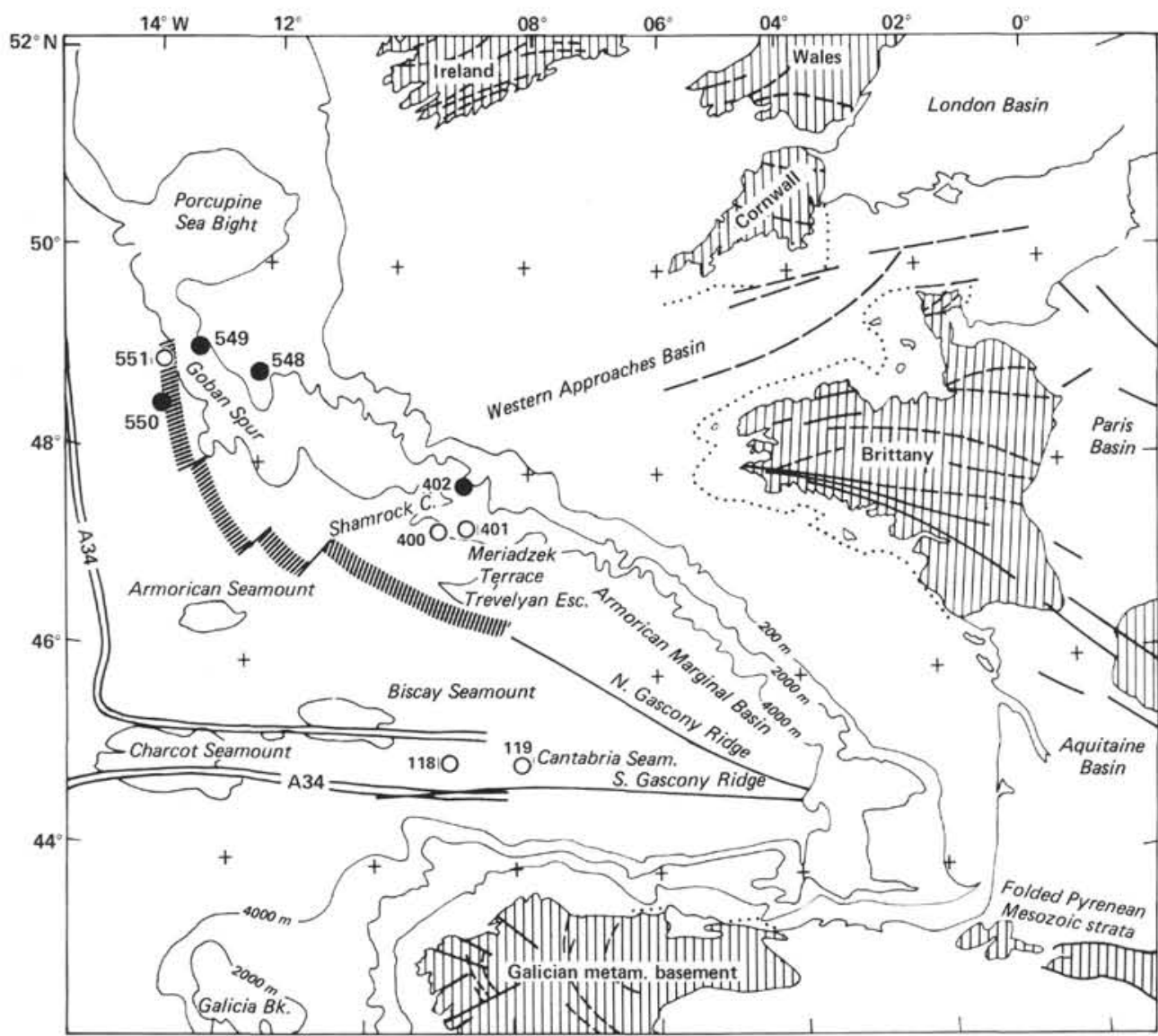

$200 \mathrm{~km}, \quad \mathbb{m}$ एा] 1
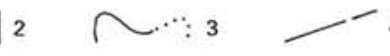

ミ三ミジ 5

Figure 1. Location map of DSDP geothermal measurements on the northern Bay of Biscay margin. Sites are shown by filled circles. Open circles represent DSDP sites at which no geothermal measurement was obtained. Main physiographic features of Western Europe and of the Bay of Biscay after Montadert et al. (1979). Magnetic Artomaly 34 after Foucher and Sibuet (1980). Key to symbols (bottom of figure): 1 = Hercynian ranges and Paleozoic basins; 2 = continent-ocean boundary (Montadert et al., 1979); $3=$ boundaries of inshore basins; blank areas inland represent the Mesozoic and Cenozoic basins; 4 = main fractured zones and faults; 5 = main Hercynian fold trends. 

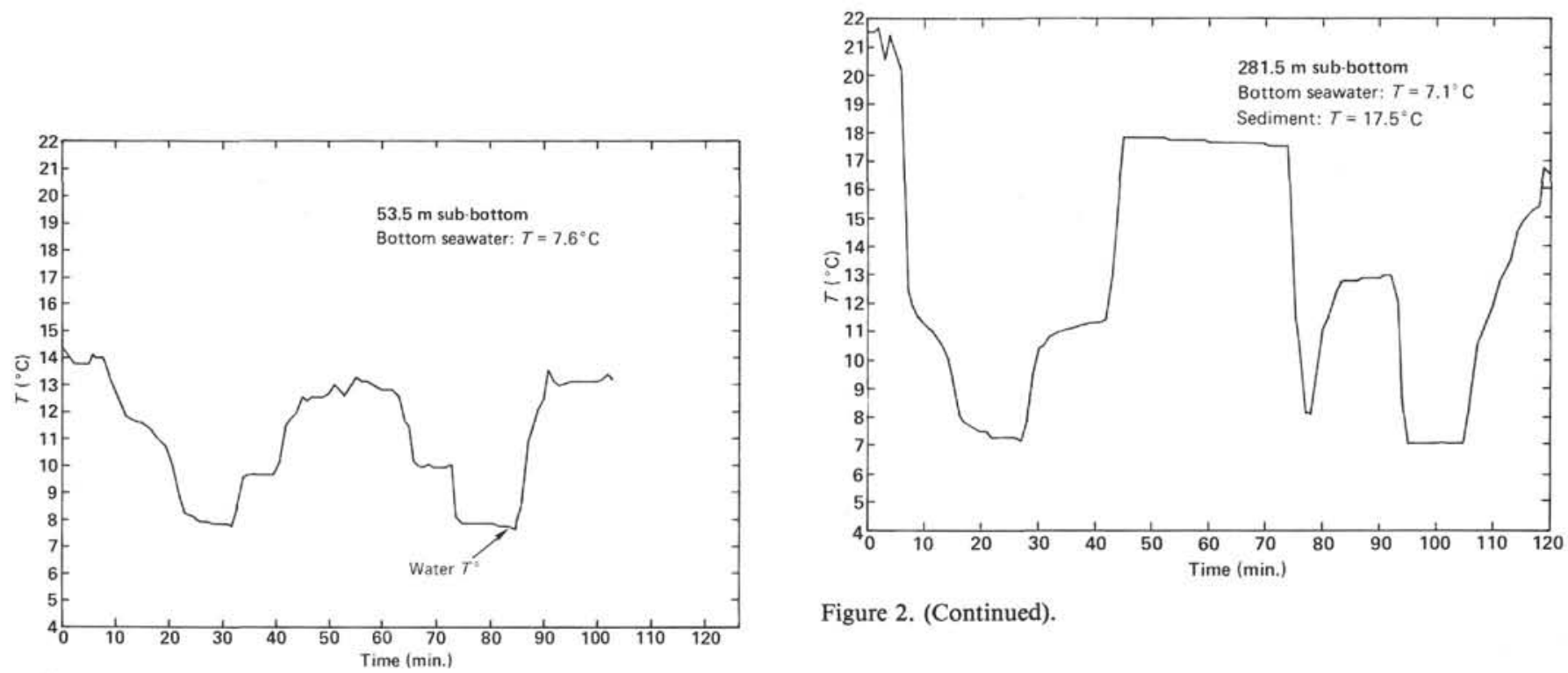

Figure 2. (Continued).
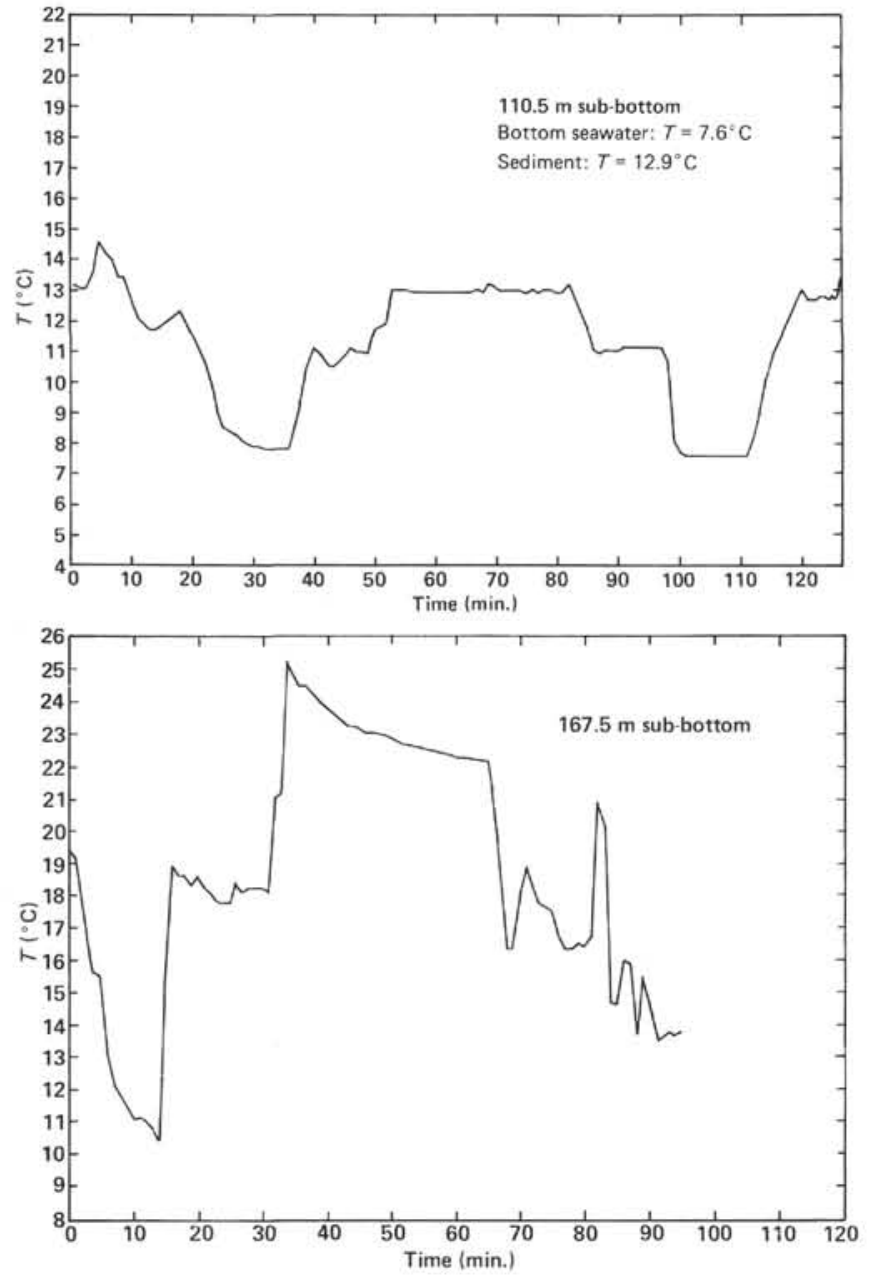

Figure 2. Temperature-versus-time records, Site 548 (Hole 548A).
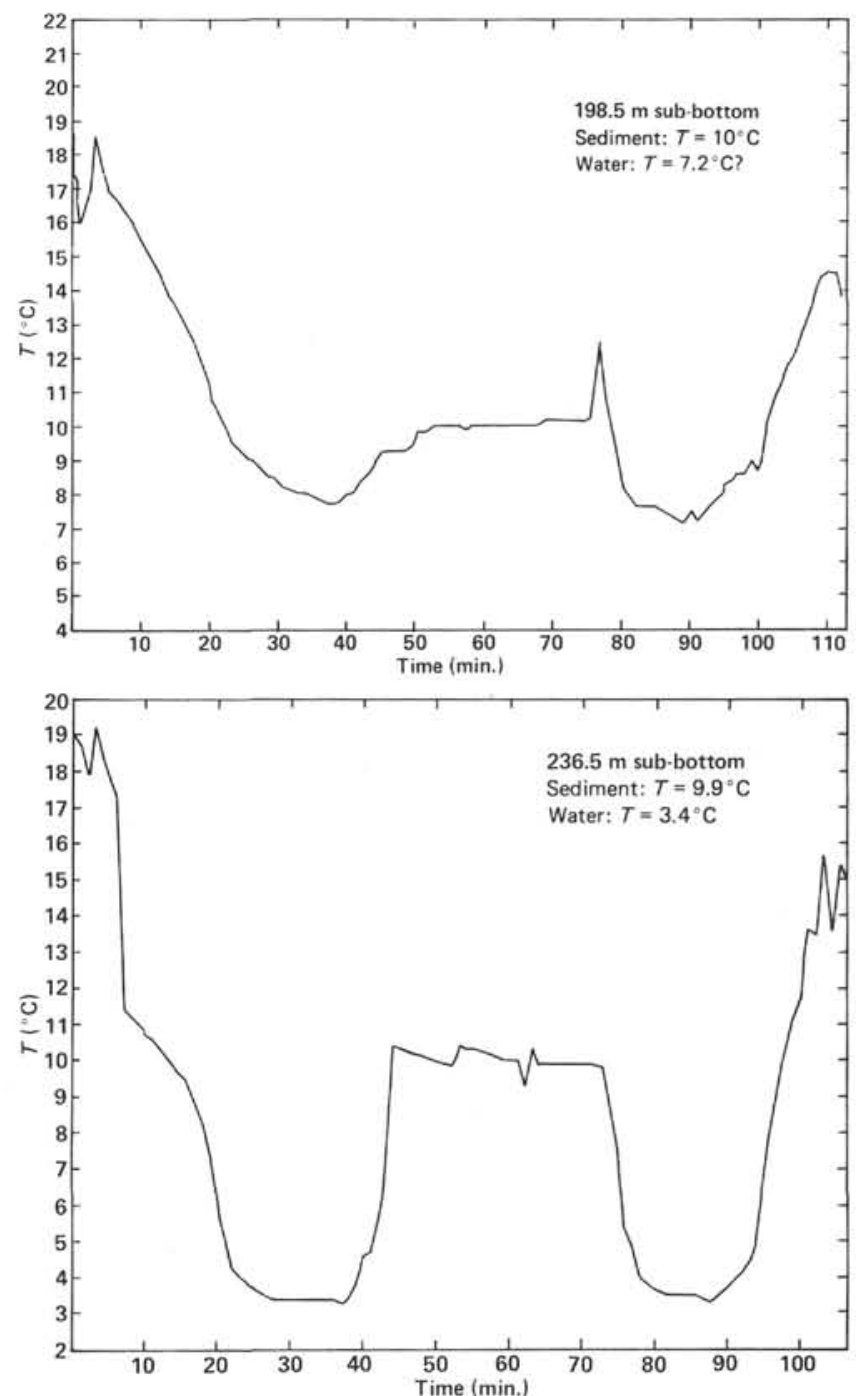

Figure 3. Temperature-versus-time records, Site 549 (Hole 549). 

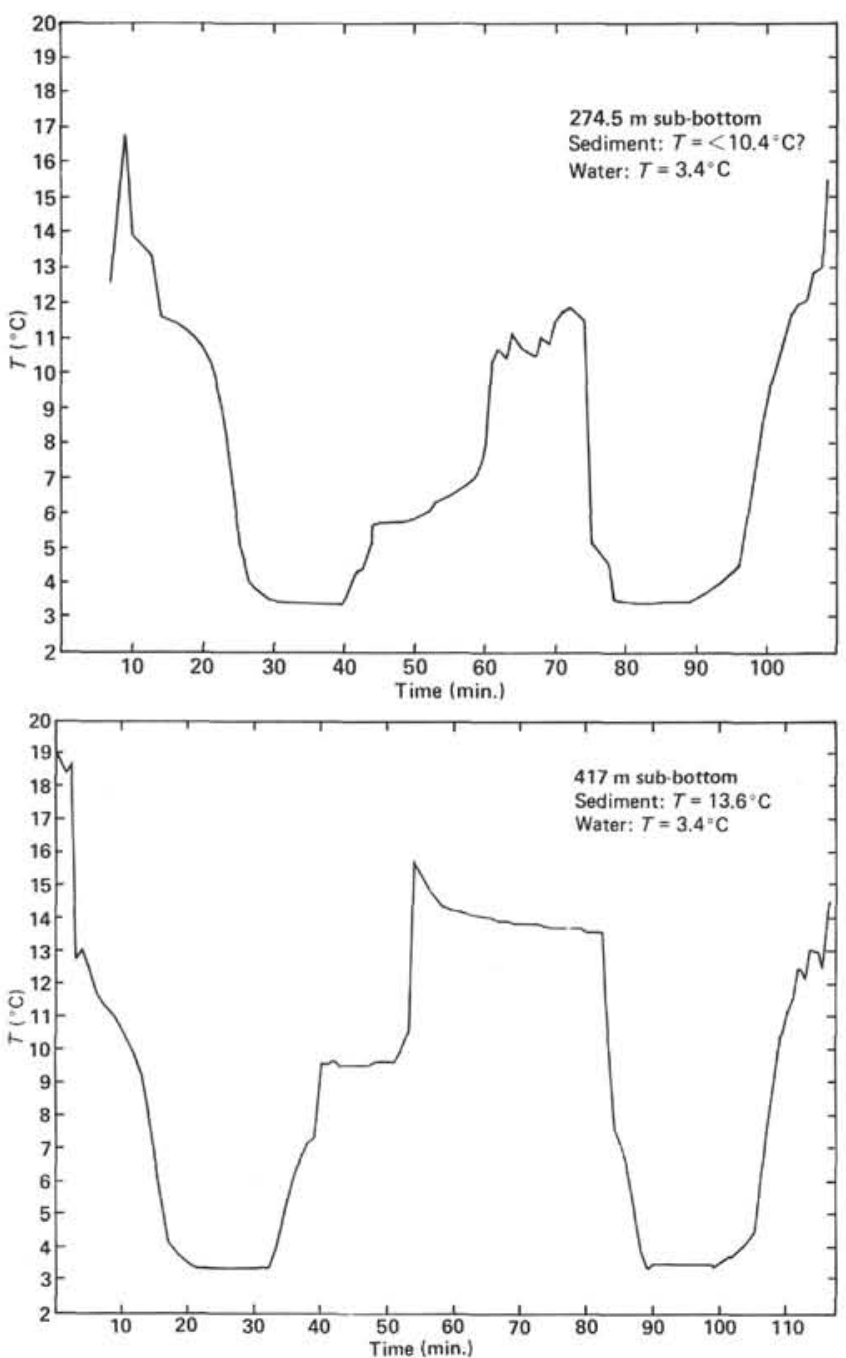

Figure 3. (Continued).

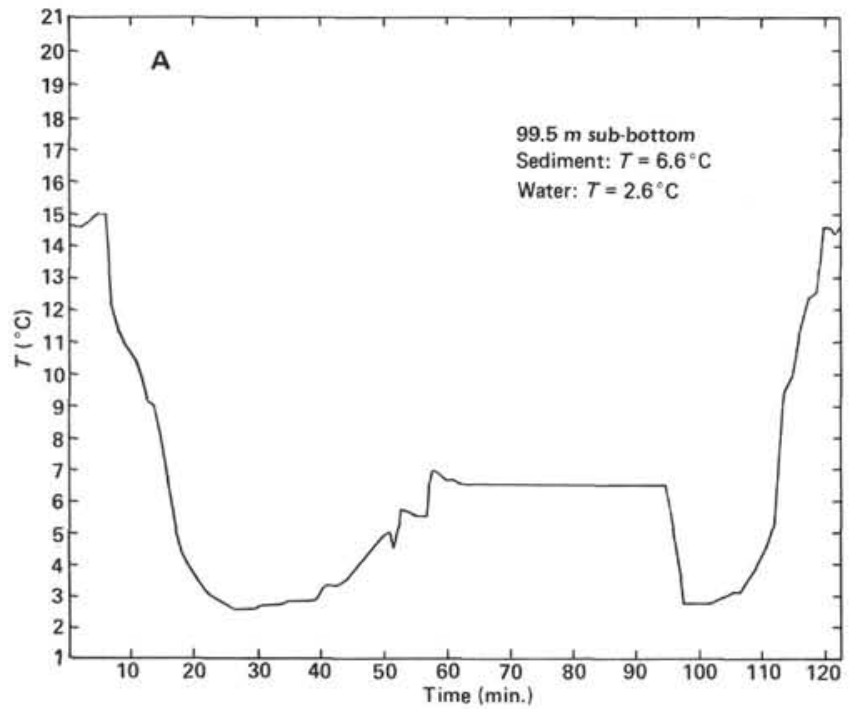

Figure 4. Temperature-versus-time records, Site 550. A-C. Hole 550. D. Hole 550B.
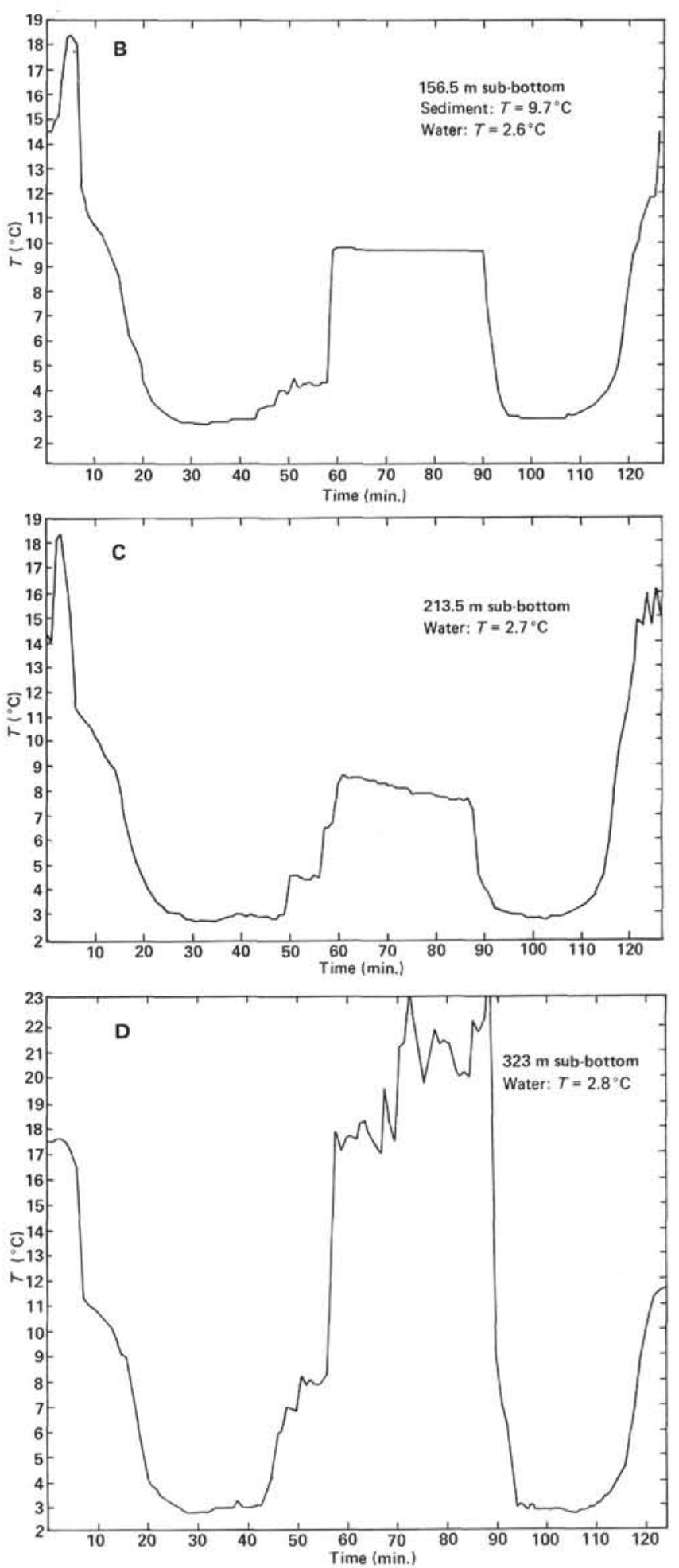

Figure 4. (Continued). 


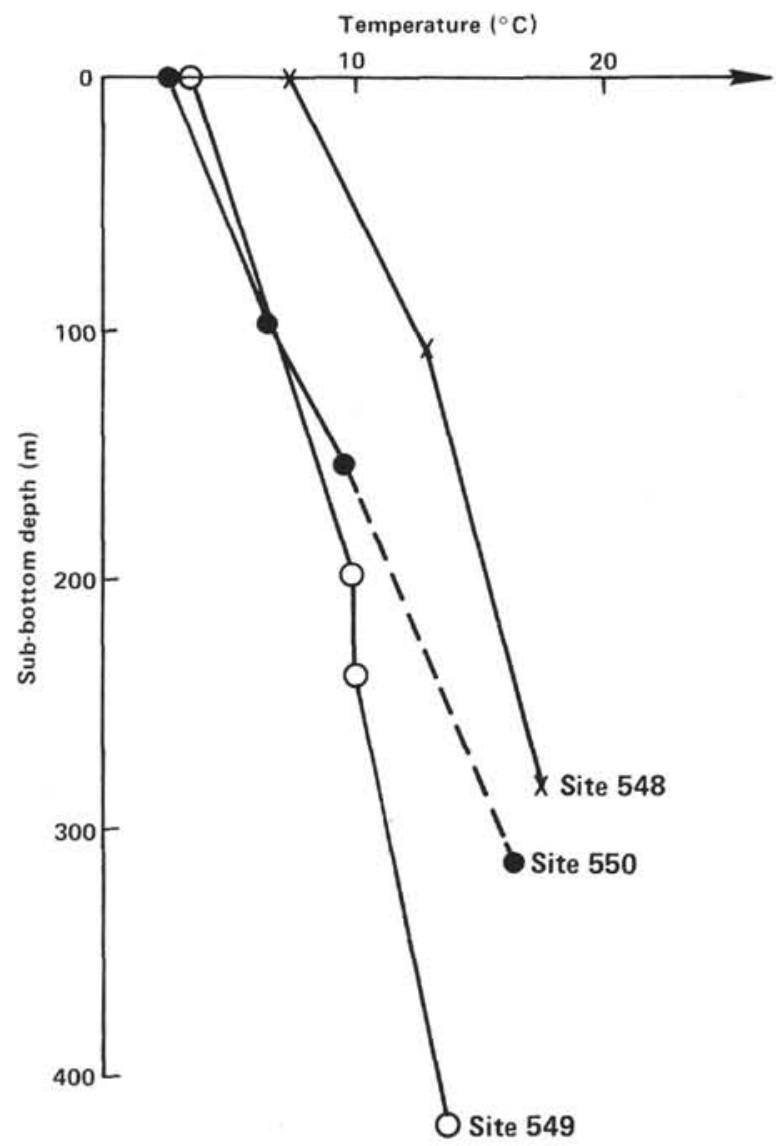

Figure 5. Temperature profiles at Sites 548, 549, and 550.

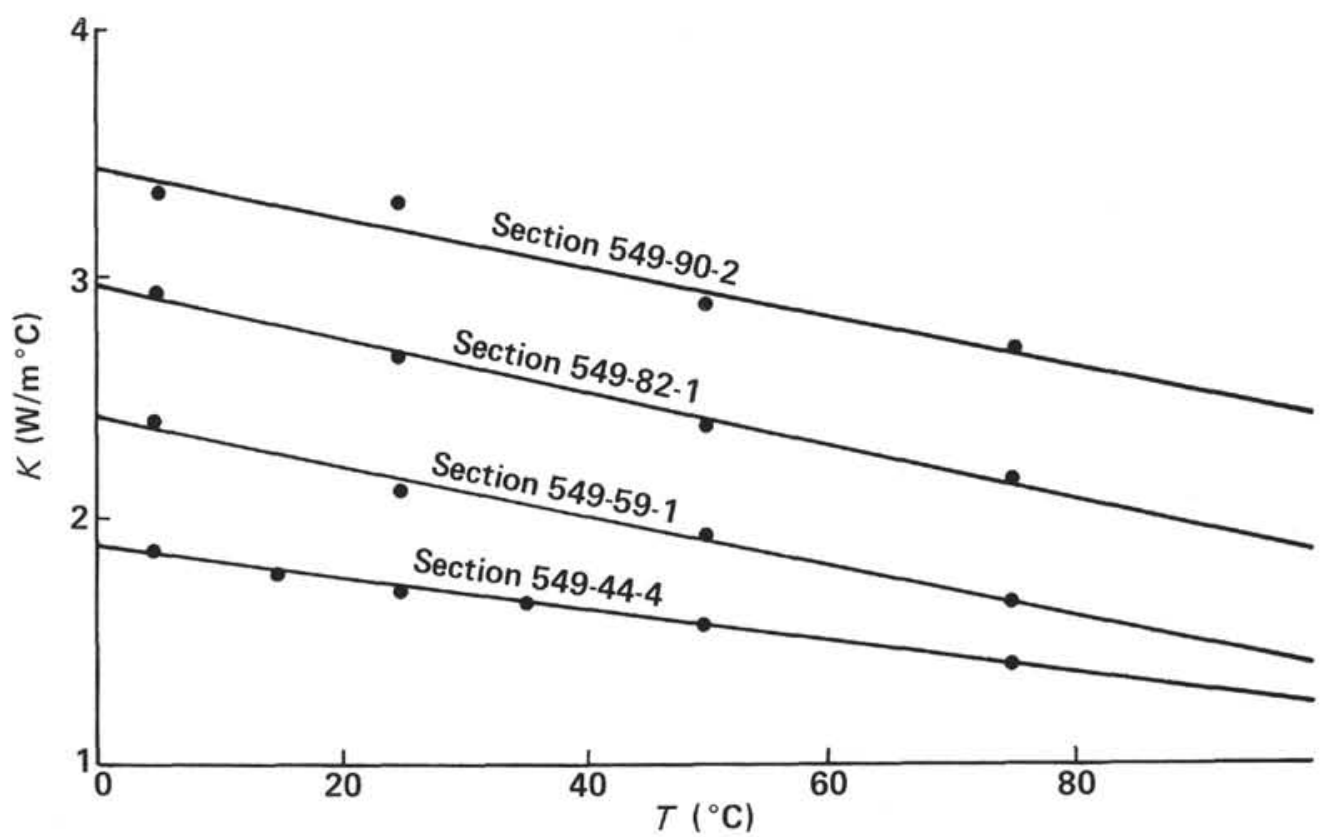

Figure 6. Plot of measured thermal conductivities versus temperature for four sedimentary samples from Hole 549. Lithologies: 549-44-4 (590 m sub-bottom), calcareous silty mudstone; 549-59-1 (730 m), calcareous sandy mudstone; 549-82-1 (875 m), sandy limestone; 549-90-2 $(930 \mathrm{~m})$, sandy siltstone. 


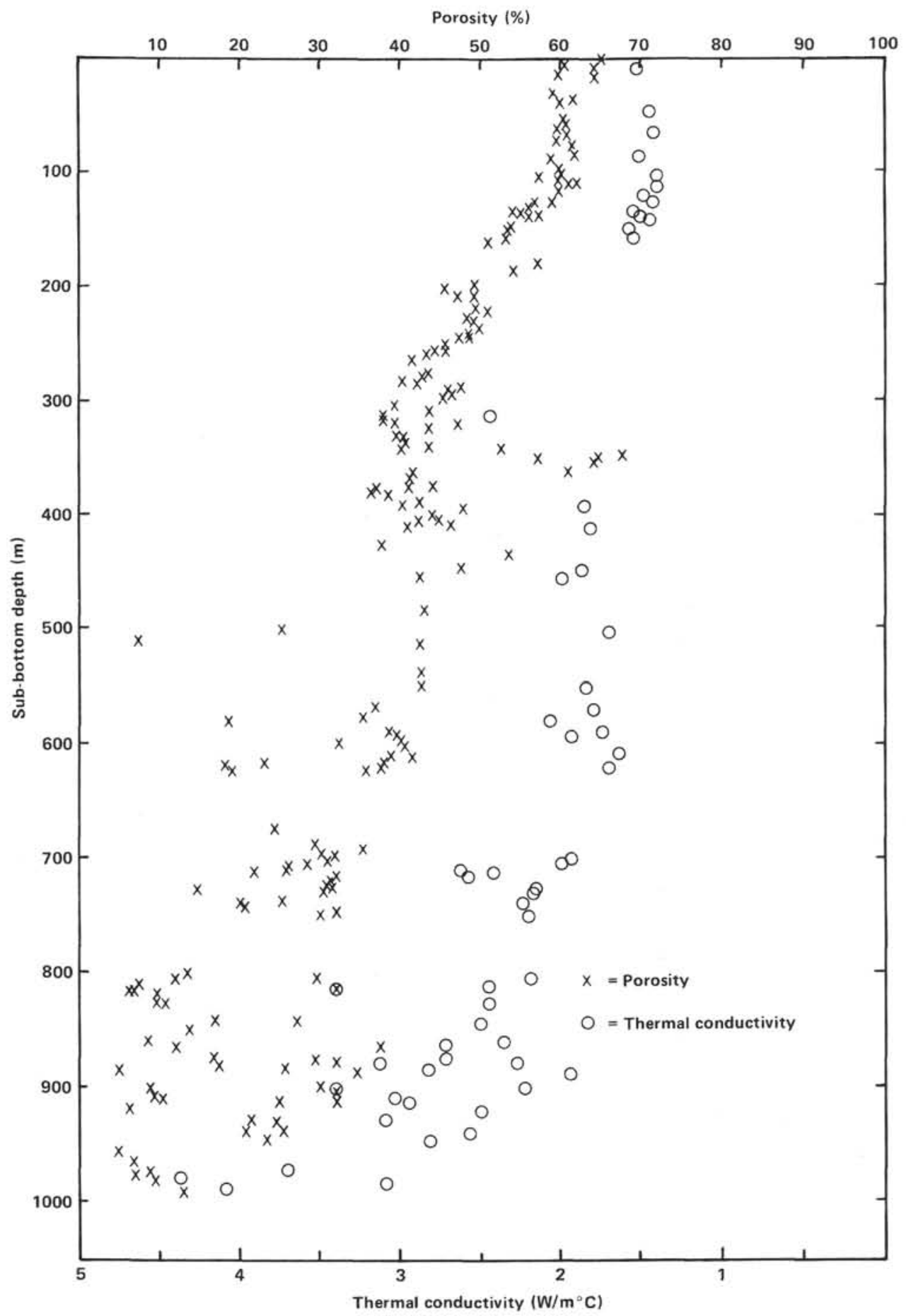

Figure 7. Plot of porosity and thermal conductivity data versus sub-bottom depth at Site 549 . 


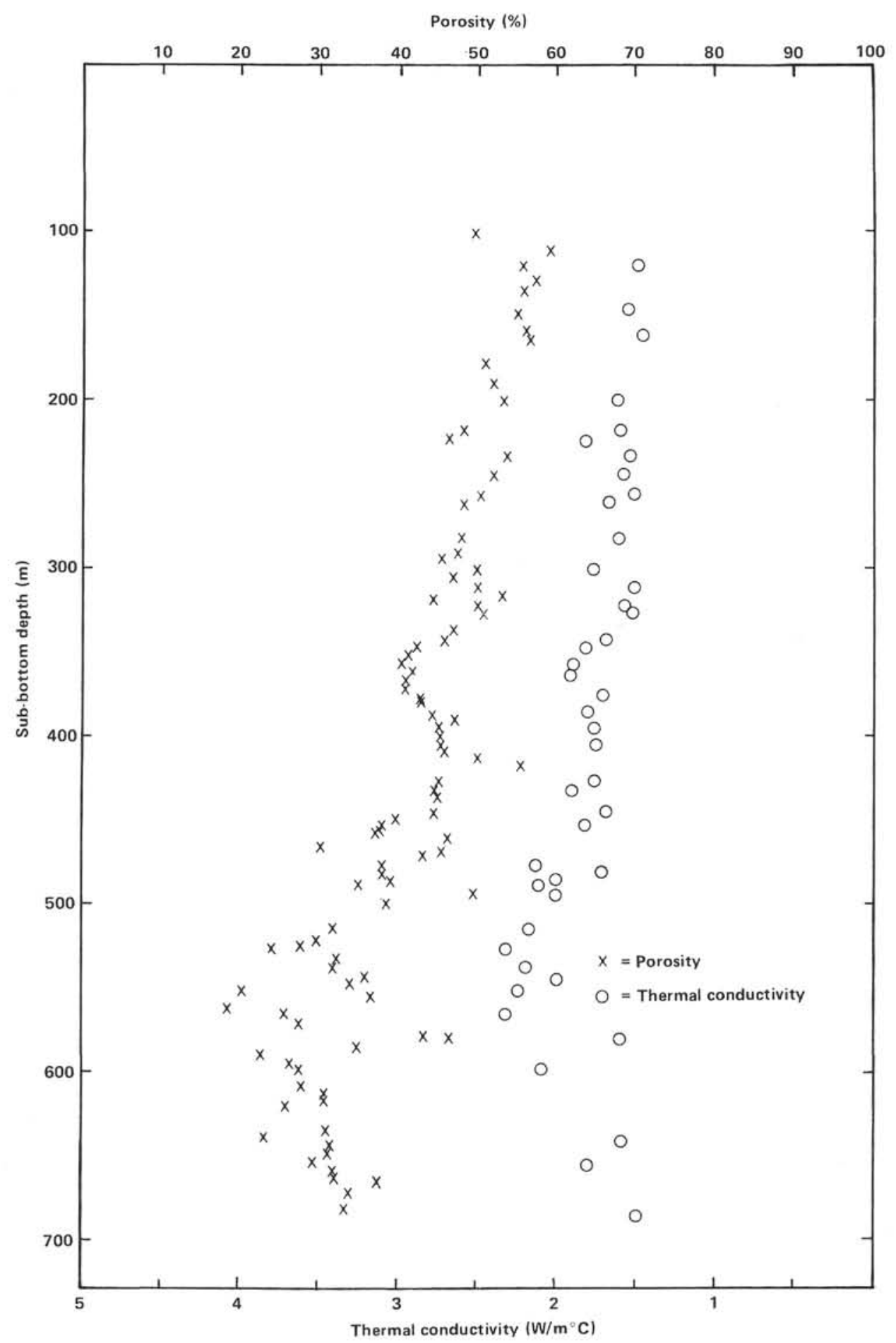

Figure 8. Plot of porosity and thermal conductivity data versus sub-bottom depth at Site 550 . 


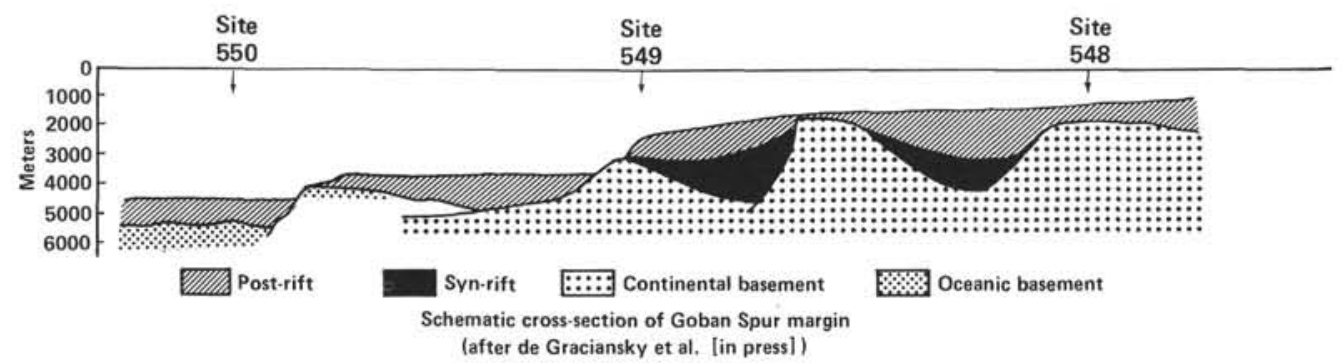

(after de Graciansky et al. [in press])

After profile CM 11

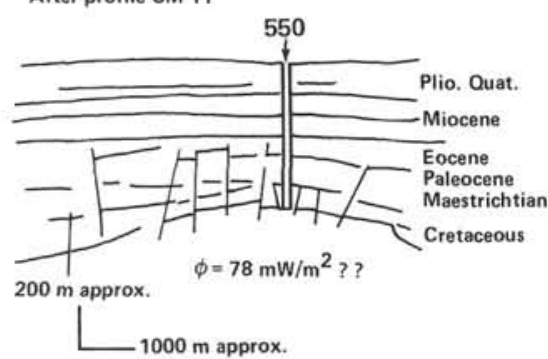

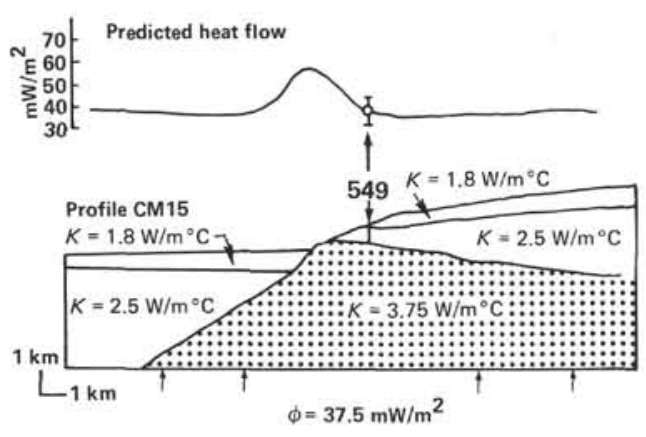

Heat-fiow variations at depth across the Goban Spur margin

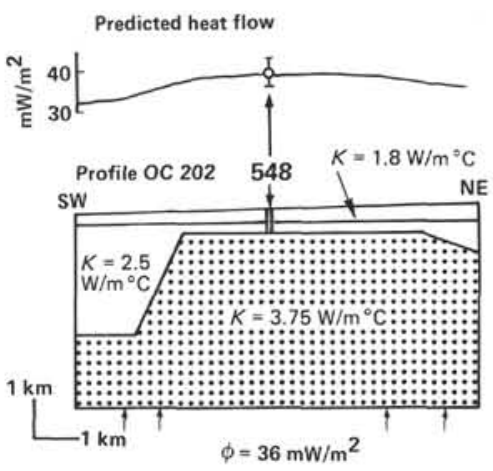

$\phi=36 \mathrm{~mW} / \mathrm{m}^{2}$

Figure 9. Two-dimensional finite-element numerical modeling of the lateral conduction effects of topography changes and thermal conductivity contrasts in the vicinity of Sites 548,549 , and 550 . A constant heat flow, defined as the corrected heat flow, $\phi$, is assumed at the base of each model, taken at a depth of $6 \mathrm{~km}$ below the sea surface.

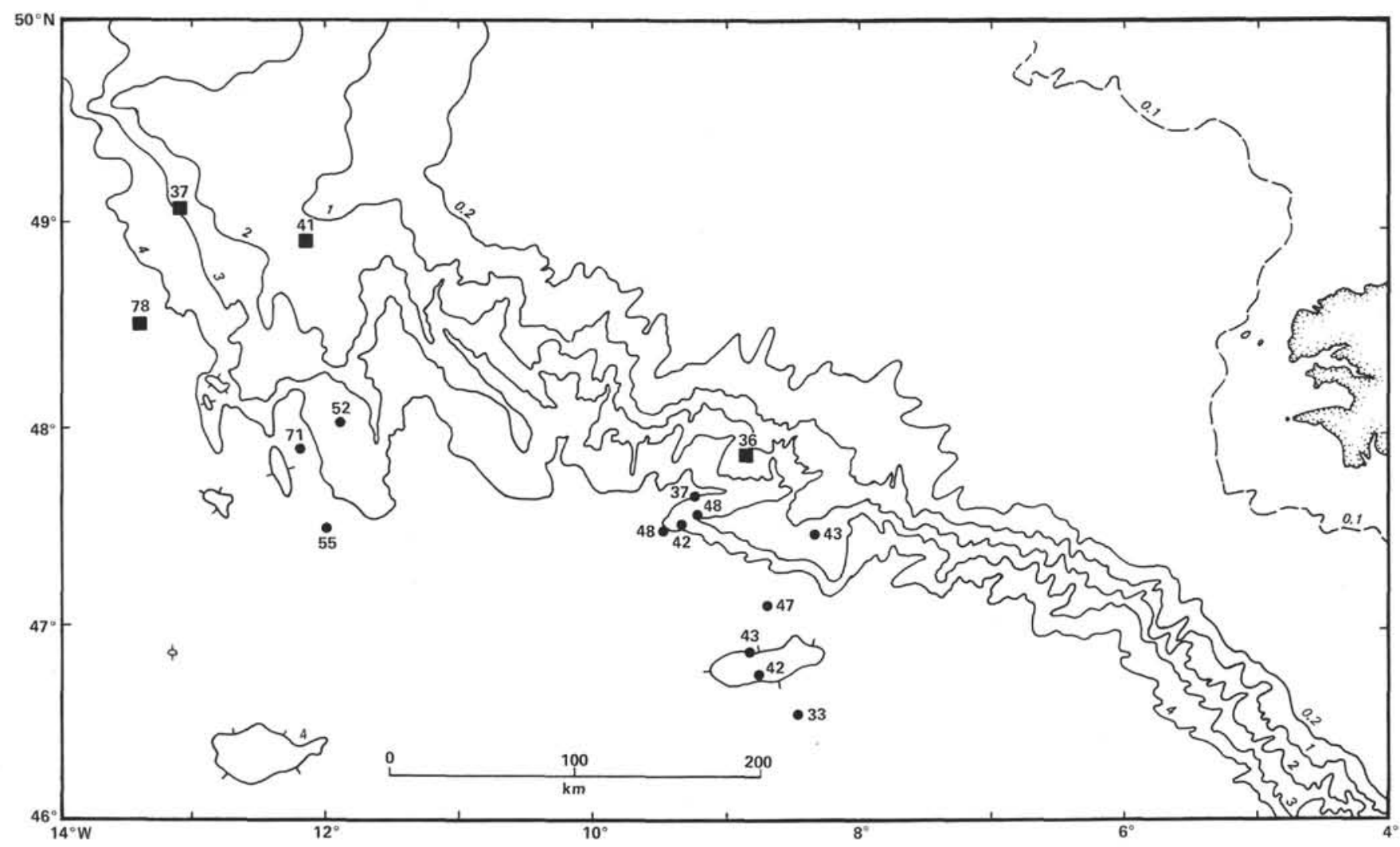

Figure 10. Compilation of available heat-flow data, including DSDP results, for the northern Bay of Biscay margin. From Erickson et al. (1979), Foucher and Sibuet (1980), and Watremez (1980). DSDP results are represented by black squares. Heat-flow values in $\mathrm{mW} / \mathrm{m}^{2}$. Bathymetry in $\mathrm{m} \times 10^{-3}$. 
A
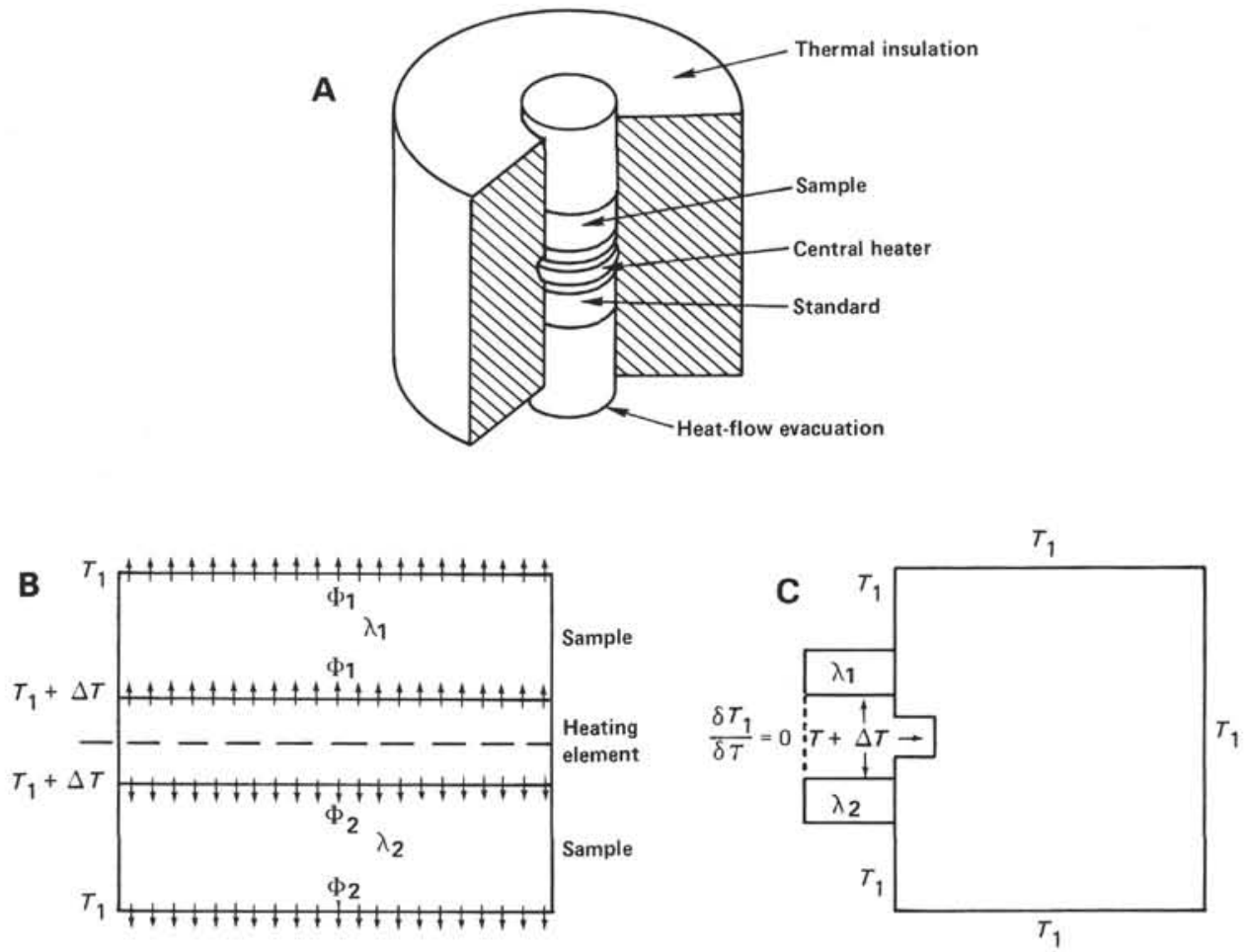

Figure 11. A. Sketch of the thermal conductivity measurement apparatus. B. Thermal state of the apparatus in steady-state conditions. C. Finite-element modeling of the apparatus with boundary conditions ( $\tau$ is time).

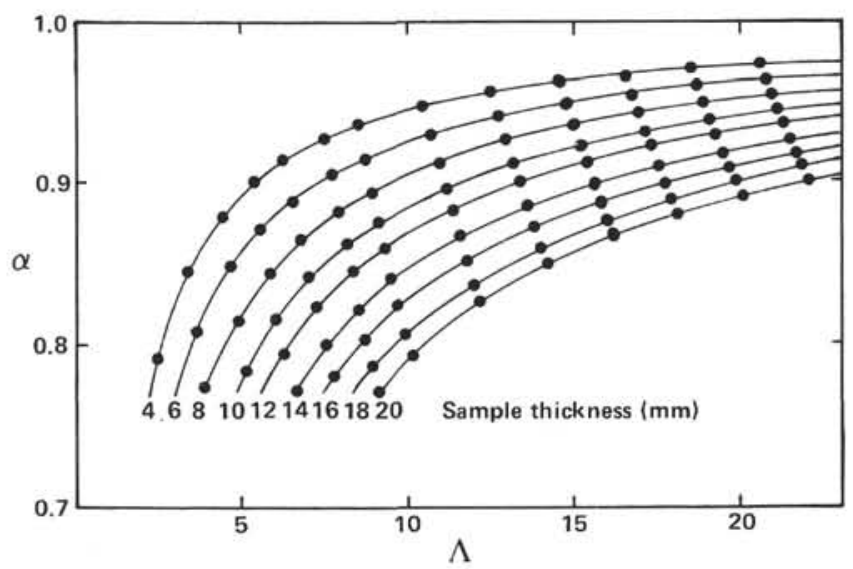

Figure 12. Plot of the correction factor, $\alpha$, versus the relative thermal conductivity, $\Lambda$, for different thicknesses of the sample, as given by the finite-element modeling. 